\title{
能動運転時及び受動運転時における緊急時行動特性の実車計測*
}

\author{
只 景 龍*1, 大武 歩*2, 河内山 隆紀*1 \\ 松岡悟*3, 山本康 典*3
}

\section{Measurement and Evaluation of the Behavioral Characteristics in an Emergency in the Active and Passive Driving of an Advanced Safety Vehicle}

\author{
Jing-Long WU*4, Ayumu OTAKE, Takanori KOCHIYAMA, \\ Satoru MATSUOKA and Yasunori YAMAMOTO \\ ${ }^{* 4}$ Department of Intelligent Mechanical Systems, Faculty of Engineering, Kagawa University. \\ 2217-20 Hayashi-cho, Takamatsu-shi, Kagawa, 761-0396 Japan
}

\begin{abstract}
Considering the emergency of pursuing the front car when a traffic signal is changing. The operation and behavior characteristics, such as response time, break pressure and stopping distance were quantificationally measured and analyzed between the passive driving of a car equipped with ACC (Adaptive Cruise Control) and the active driving of a car without ACC. Acording to the results, while there was a dependence between the speed and the headway distance in the active driving, it was not found in the passive driving, with respect to the response time. In the case of the time of break pressing, the results were reversed with respect to the response time. Furthermore, during passive driving, even at the emergent conditions, such as fast speed and short headway distance, the breaking pressure can achieve greater value in a shorter time.
\end{abstract}

Key Words: Advanced Safety Vehicle, Adaptive Cruise Control, Reaction Time, Braking Operation, Stop-distance

\section{1. 緒 論}

近年, 高度道路交通システム(ITS)の急速な発展に ともない, 自動料金収受システムなどに代表されるイ ンフラストラクチャーの整備や安全運転支援システム などが開発され，私たちの自動車の運転環境はまた一 歩新しい段階へと進んでいる.

その一翼を担う先進安全自動車(ASV: Advanced Safety Vehicle)は, エレクトロニクス技術の応用で車 両を知能化することによって, 安全性の格段の向上を 狙った次世代の自動車である ${ }^{(1)}$. ASV に搭載される 安全技術の 1 つに, ACC(Adaptive Cruise Control)シ ステムがある. 本システムでは, バンパー部分に取り 付けられたミリ波レーダ, レーザレーダ, 超音波セン サなどの距離センサやカメラによる画像認識を用いる ことで先行車両や歩行者を察知することを可能にする (2) .このような装置から得られる車外情報をもとに, ドライバに危険を知らせたり, コンピュータ制御でア クセル・ブレーキペダルを操作したりすることができ

* 原稿受付 2005 年 9 月 2 日.

*1 正員, 香川大学工学部 (亚 761-0396 高松市林町 2217-2).

*2 香川大学大学院工学研究科.

*3 マツダ(株) (\$730-8670 広島県安芸郡府中町新地 3-1).

E-mail : wu@eng.kagawa-u.ac.jp
ることから, ACC システムは, ドライバの負担軽減 や安全運転の支援に大きく貢献すると期待されている. しかしながら，このような新技術は，これまでの自動 車の操作性を大きく変えてしまうことにもなり, 延い ては，不安全運転をもたらす可能性もあるため®， 導入に際しては慎重な検計が必要とされている中．

そこで本研究では, ACC システムに依存した運転 状態において, 急ブレーキなどの緊急を要する事態に 直面したときのドライバの操作・行動特性を実車実験 にて計測することで, 交通安全上特に重要である緊急 時運転行動に ACC システムがもたらす影響を検証し た.

\section{2. 自動車过枟行動における能勤性と受勤性}

我々は, 先進安全自動車の問題点として，運転 操作を自動化することにより, 運転者の疲労・負担 を軽減する反面, 運転という「能動的行動」を「受 動的行動」に変えてしまうことを提起する ${ }^{(5)} \sim(7)$. 通常の運転では, ドライバ自身がアクセル・ブレー キ操作することで自らの運転意思を車に伝えている. 
これを能動運転と定義する. 我々は, 感覚器官で車 内・車外情報を認知し, 中枢神経でそれらを判断し， 運動器官で操作を行う.それが自動車の挙動となり, そうして得られる車内・車外情報を再ひ認知し, 判 断して, 行動するというサイクルを繰り返して運転 をしている. 一方, 速度調節を ACC システムによ り自動化した自動車では, コンピュータがアクセ ル・ブレーキ操作を行う. その結果, アクセル・ブレ 一キ操作において, 自動車はドライバの運転意識に 関係なく動作する. 本実験では, このような状態を 受動運転と定義する.

ここで, 能動運転と受動運転の違いが明らかと なる. すなわち, 能動運転時では, 運転行動とその 結果としての感覚情報は相互に関係性を持ち, アク セル・ブレーキ操作というドライバの運転行動と速 度感や加速度感に係わる視覚・体性感覚情報が相互 に関係していると言える. ところが，ACC システ ムに依存した受動運転時では, そのような感覚情報 は, 行為とは独立なものとして知覚される.

このように異なる運転状態にあるドライバは, 緊急を要する事象に直面した時にどのような行動を とるであろうか. これは, 今後 ACC システムを搭 載した ASV が普及していく可能性を考えると検証 しておくべき重要な課題であるといえる.

本研究では, 先行車両を比較的低速度で能動的 あるいは受動的に追従しているドライバが，交差点 で緊急停止をしなければならない状況を想定し，そ の時のドライバの行動特性を複数のパラメータで計 測した.

\section{3. 実車による行動学実跙}

3.1 実験車両 実車実験における実験車両は, 乗 用自動車 (ミニバン型) のオートマチック車で, 総 排気量は $2300 \mathrm{cc}$ である。本実験車両は, 二次元ス キャン式レーザレーダを用いた ACC システムを搭 載している。本システムは, レーダによって計測さ れた前方車両との距離情報を用いることで、ドライ バがペダル操作をすることなく, 設定された車間距 離及び車速を維持することができる. また運転者の 運転行動を測定し記録するために, 同車に搭載され たカメラ及び各種計測センサにより, 車内・前方画 像, 車間距離, ブレーキ圧変化, 速度・加速度の時 系列データを計測した。

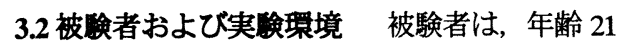
歳から 24 歳までの自動車免許を保有した健常男性 3 名である. 実験は, 香川県警察本部運転免許セン
ター内の標準信号機のある交差点を含んだ 1 周 $500 \mathrm{~m}$ の周回コースにて実施した. 信号制御のため, 3 名の実験者を交差点に配置した. 図 1 に実験に使 用したコースの概要を示す.

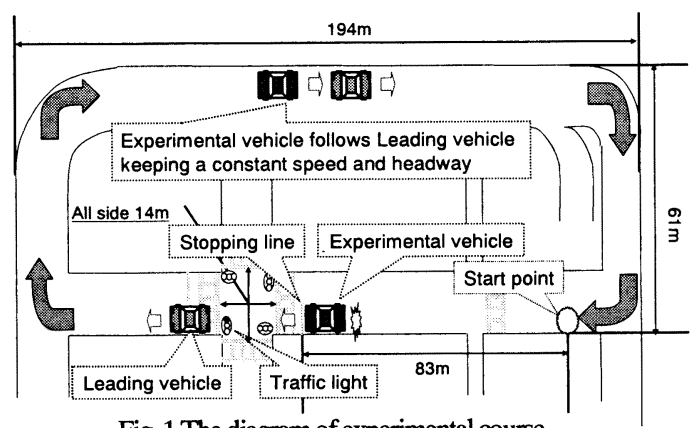

Fig. 1 The diagram of experimental course

33 実験課題 能動実験では被験者がアクセル・ ブレーキ操作を行い, 受動実験では ACC システム の先行車自動追従機能によってそれらの操作を行っ た。ただし, 両実験ともにハンドル操作は, 被験者 が行った. また 3 名の被験者全員が両条件を行った.

課題は, 追従時における緊急停止課題である. 本課題における緊急事象は, ドライバが先行車両を 追従しながら交差点に侵入する際に, 突然停止信号 が表示されるものとした. 被験者へは, 実験説明時 と実験車両乗車時に交差点の停止信号に従わなけれ ばならない旨を教示し, ' 緊急事象であることを理解 させた.

追従をする際の先行車両の車速及び先行車両と 実験車両の車間距離の条件は, 実験中における被験 者の安全と実験コースによる制限を考慮し表 1 に示 す 6 条件に設定した（表 1）. 各車速・車間距離の 組み合わせを 1 実験ブロックと定義する. なお， 6 条件の実施の順番は被験者間でランダムとした.

Table 1 Experimental setup for speed and headway of the leading vehicle

\begin{tabular}{|l|l|l|l|}
\hline Speed & \multicolumn{3}{|c|}{ Headway } \\
\hline $20 \mathrm{~km} / \mathrm{h}$ & $10 \mathrm{~m}$ & & \\
\hline $25 \mathrm{~km} / \mathrm{h}$ & $10 \mathrm{~m}$ & $15 \mathrm{~m}$ & \\
\hline $30 \mathrm{~km} / \mathrm{h}$ & $10 \mathrm{~m}$ & $15 \mathrm{~m}$ & $20 \mathrm{~m}$ \\
\hline
\end{tabular}

実験の流れは，以下の通りである. まず，乗下 車位置にて, 先行車両に実験者 1 名, 実験車両に被 験者と実験者の計 2 名の全 3 名が乗車した. 実験車 両における実験者は, デー夕収集に加えて, 同車車 速と先行車両との車間距離を監視して，それが各設 定条件より土 $5 \mathrm{~m}$ 以上乘離した場合に被験者への教 示を行った. 実験試行開始前に, 実験車両の加速特 性やブレーキ特性に慣れてもらうための訓練試行を 
設けた．訓練試行では，ACC システムを動作させ， 車速 $30 \mathrm{~km} / \mathrm{h}$, 車間距離 $15 \mathrm{~m}$ にて先行車両を追従の 上，コースを 15 分間周回させた. この際，本シス テム特有の自動停車機能なども体験させた.

実験試行開始の際に，被験者に以下の指示を行 った. まず，能動・受動運転課題共通に，「追従運 転中, 交差点において信号が黄色に変わった時に, 停止線までに停車すること」を指示した. 次に, 能 動運転時には，「道路交通法に基づいて，アクセ ル・ブレーキを操作して運転すること」，「同乗す る実験者の指示に従い，設定された車速·車間距離 にあわせて走行すること」を指示した. 受動運転時 には，「ブレーキ操作時以外は右足を床面に置いて おくこと」，「ACC システムが停止したときは素 早く動作しなおすこと」を指示した.

実験車両は，各ブロックで決められた車速・車間 距離を維持しながら先行車両を追従し, 周回コース を 10 周した. この時, 交差点の信号機は, 被験者 ごとに決められたランダムな信号制御系列に基づい て 50\%の確率（全 10 周中，5 回の割合）で青色か ら黄色へと切り替えられた. 信号の変わる時点は, 先行車両の前輪が，停止線を通過した時点とした

（図 1）. 先行車両は，そのまま交差点に進入し， その後, 交差点先で停車した. 一方, 実験車両は, 交差点に進入しないように停止線までに停止しなけ ればならない，実験車両が緊急停止後，安全を確認 した後, 再び追従走行を開始した. 10 周の実験試 行が完了後, 両車両はスタート地点まで戻り, 1 実 験ブロックは終了する. 2-3 分の休咊の後, 次の実 験ブロックを開始した.

3.4 計測テータおよび解析 本報告では，(1)車 内・車外前方のビデオ画像，(2)実験車両のブレーキ 圧時系列デー夕, (3)速度時系列デー夕, (4)走行距離 時系列デー夕を用いて，被験者毎に下記の解析デー 夕を算出した.

本研究では，緊急時行動を複数の行動要素から成 る複合的行動と考えており，それに応じた複数の行 動時間を設定した. すなわち, 交差点信号機が黄色 信号に変わってから引き続きブレーキペダル操作を 開始するまでの時間を反応時間（A），ブレーキぺ ダルを最も踏み込むまでの時間をブレ一キ踏み込み

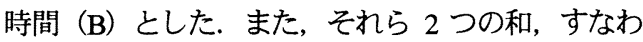
ち交差点信号機が黄色信号に変わってからブレ一キ ペダルを最も踏み込むまでの時間を最大ブレ一キ圧 時間（C）とした．さらに（D）最大ブレ一キ圧と (E) 停止距離も解析した.
（A）－（D）は，ビデオ画像から検出した信号変 化時点をトリガとしてブレーキ圧データ（図 2）か ら次のように読み取った。（A）は，信号変化時点 からブレ一キ圧の立ち上がり時点までの時間である。

（C）は，信号変化時点からブレ一キ圧が最大值と なるまでの時間，（B）は, （C）と（A）の差で与 えられる. なお，最大ブレ一キ圧（D）を決定する 基準は, 信号変化時点から 3 秒間でのブレ一キ圧時 系列データの最大値とした. （E）は, 信号変化時 点から速度時系列データがゼロになるまでの時点を 検出し, 走行距離時系列データより算出した.

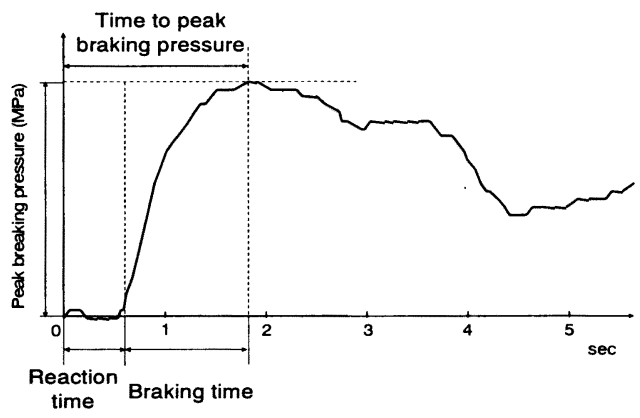

Fig. 2 Measurement for braking pressure time series

解析デー夕は, 統計的に評価した. 統計解析に は, SPSS 12.0J（SPSS Japan Inc.，Tokyo，Japan）の一 般化線形モデルを用いた．被験者が少ないため，各 個人のデータをプールして固定効果モデルを構筑し た. 実験計画は，運転状態 (2 水準) $\times$ 車速あるい は車間距離条件（3 水準）の 2 要因分散分析であり, 関心外因子として被験者要因を加えた. また下位検 定には，ボンフェロー二の多重比較検定を利用した 統計解析における有意水準は, 5\%に設定した.

\section{4. 实 臨结果}

4.1 ブレーキ圧データ 図3には, 各被験者のブ レ一キ圧を示した. グラフは，5試行の加算平均の 結果である. 図 3(A)には, 一定車速条件下

$(30 \mathrm{~km} / \mathrm{h})$ ）車間距離別のブレ一キ圧の推移を示し た. 縦軸はブレーキ圧（MPa）を，横軸は時間軸を 示す. 受動運転時（右側グラフ）, 能動運転時（左 側グラフ）ともに，車間距離が長くなるほどブレ一 キ圧の振幅が小さくなり，ブレ一キ圧の立ち上がり が緩やかである．また，ブレ一キ圧を緩めるまでの 時間は，車間距離が短いほど短い。また，ブレーキ 圧を緩めるまでの時間は車速が速いほど短くなる傾 向が見られる. 図 3(B)には, 一定車間距離条件下 (10m)，車速別のブレ一キ圧の推移を示した．図 
より, 受動運転時, 能動運転時の双方で, 車速が速 いほどブレーキ圧の立ち上がりが急で, かつ振幅も 大きくなる傾向がある. また, ブレーキ圧を緩める までの時間は車速が速いほど短い．図 3(A)と図 3(B) より, 能動・受動の両実験結果を比較すると, 受動 運転時のほうが能動運転時よりもブレーキ圧の立ち 上がり方が急で振幅が大きくなる傾向がみられる. 以下では, 3.4 の解析法に基づき, 定量的な評価を 行った.

(A) Speed $30 \mathrm{~km} / \mathrm{h}$

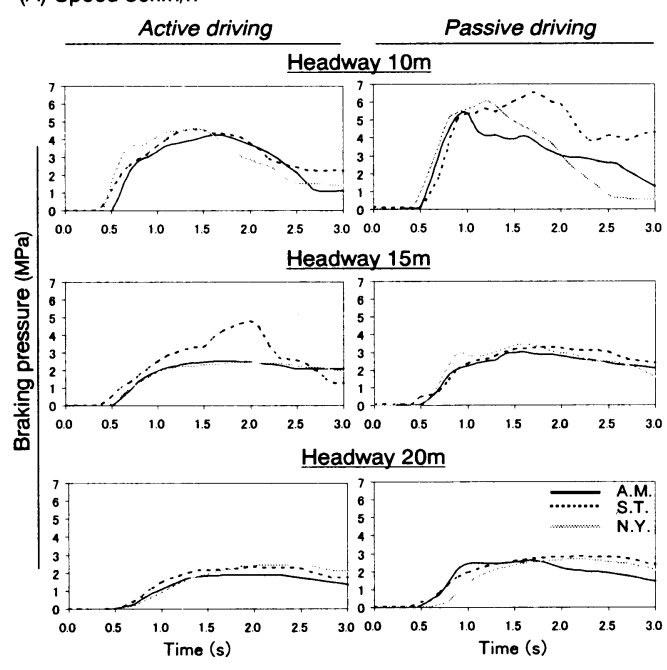

(B) Headway $10 \mathrm{~km} / \mathrm{h}$

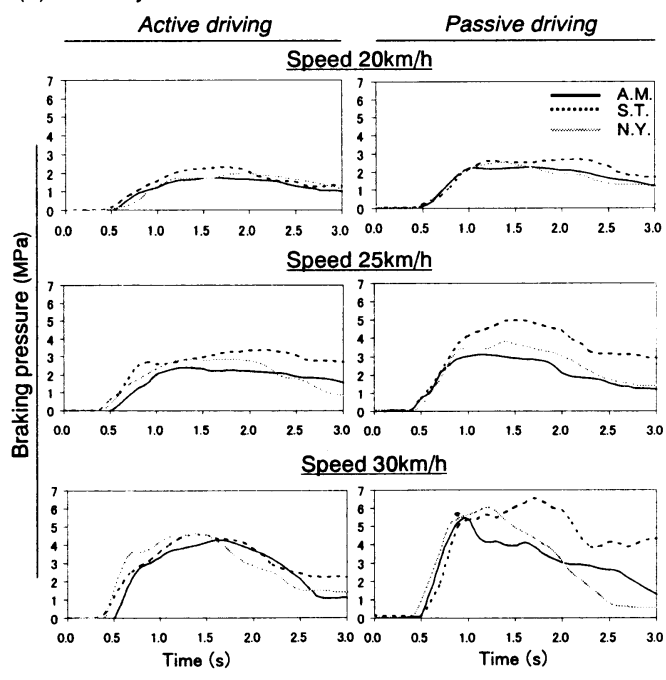

Fig. 3 Time course of braking pressure for each subject under constant speed (A) and headway (B)

4.2 反応時間 図 4(A)に能動運転実験での, 図 4(B)に受動運転実験での各被験者・各実験条件にお ける平均反応時間を示す. 縦軸は反応時間を, 横軸
は実験条件(車速・車間距離)をそれぞれ示す．黑色 のグラフは被験者 A.M., 斜線のグラフは被験者 S.T., そして白色のグラフは被験者 N.Y.のデータである.

受動運転実験時には, 能動運転実験時のような車 速および車間距離の依存性が顕著に見られなかった. またグラフから, 能動運転実験時には, 一定車速条 件下では車間距離が長くなるほど反応時間が長くな り, 一定車間距離条件下では, 車速が速いほど反応 時間が短くなることが示唆される. そこで, 同一車 間距離下において, 車速の違いが反応時間に与える 影響を検討した.

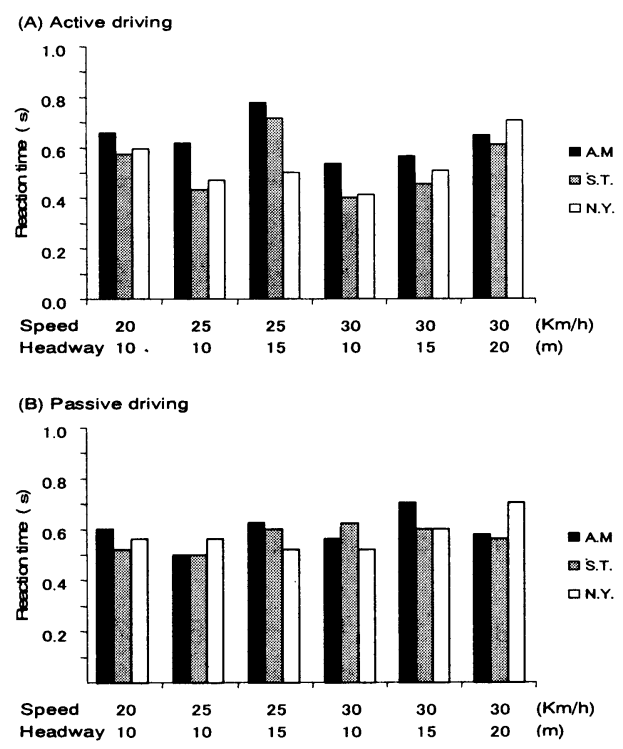

Fig. 4 Averaged reaction time in each experimental condition of (A) active and (B) passive driving experiment

図 5(A)は, 3 人の被験者の平均值である. 誤差バ 一は, 全データの標準誤差を示す. 分散分析の結果, 車速の主効果および車速と運転状態の交互作用が有 意であった.（車速 : $F(2,82)=5.27, \mathrm{P}<0.01$; 車速 $\times$ 運転状態: $F(2,82)=5.41, P<0.01)$. 交互作用が有意 であったので, 下位検定を実施した. その結果, 能 動運転においてのみ車速の増加とともに反応時間が 減少するという速度依存性が存在した。速度 $30 \mathrm{~km} / \mathrm{h}$ 条件において受動状態と能動状態に反応時 間の差が見られたが，平均的には有意とは言えなか った（運転状態 : $\mathrm{F}(2,82)=0.783, \mathrm{P}=0.393$ ）.

同様に, 同一車速において, 車間距離の違いが 反応時間に与える影響を検討した（図 5(B)）. 分散 分析の結果, 車間距離, 運転状態の主効果および車 間距離と運転状態の交互作用が有意であった.（車 速 : $F(2,82)=7.33, P<0.01$; 運転状態 : $F(2,82)=5.37$, 
$\mathrm{P}<0.05$; 車間距離 $\times$ 運転状態: $\mathrm{F}(2,82)=3.66$, $\mathrm{P}<0.05 ＼mathrm{~ ） ~ 下 位 検 定 の 結 果, ~ 能 動 状 態 に お い て の み ~}$ 車間距離の増加とともに反応時間が増加する車間距 離依存性が存在した。車間距離 $10 \mathrm{~m}, 15 \mathrm{~m}$ 条件では, 受動状態と能動状態の間で反応時間の差が見られた。
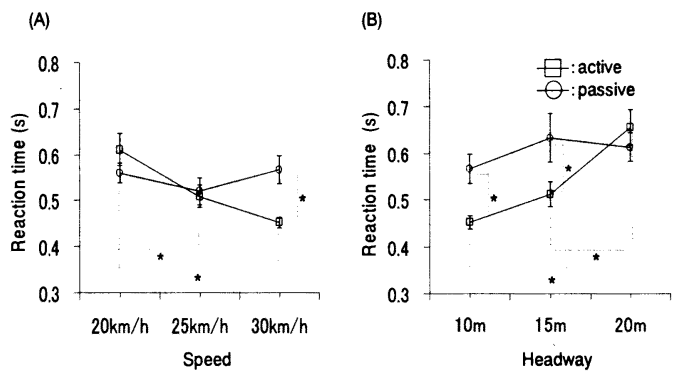

Fig. 5 Reaction time averaged by three subjects. (A) Speed dependence, (B) Headway dependence

4.3 最大ブレーキ圧時間 図6 (A) には, 最大 ブレ一キ圧時間の同一車間距離における車速依存性 を示した. グラフは, 3 人の被験者の平均值で示し た. 誤差バーは, 全データの標準誤差である. 分散 分析の結果, 車速の主効果のみ有意であった（車 速 : $F(2,82)=5.34, P<0.01)$. 能動運転における車速 $15 \mathrm{~m}$ と $20 \mathrm{~m}$ 条件間を除いて, 能動・受動運転とも に速度が高いほど短時間で最大值に達する傾向があ った.

図 6 （B）には, 最大ブレ一キ圧時間の同一車速 における車間距離依存性を示した．分散分析の結果, 車間距離の主効果のみ有意であった（車間距離： $\mathrm{F}(2,82)=14.5, \mathrm{P}<0.01)$. 能動 - 受動運転ともに車間 距離の減少とともに最大值になるまでの時間が減少 した.
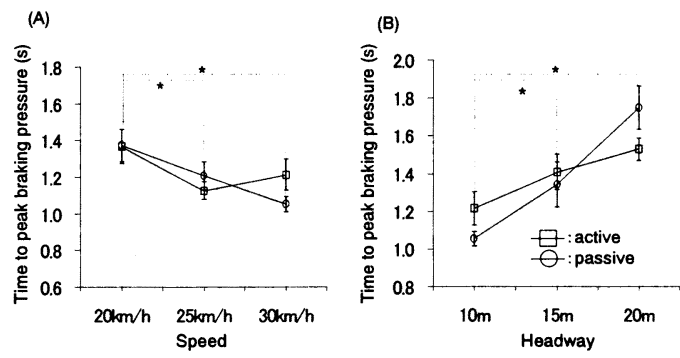

Fig. 6 Time to peak braking pressure averaged by three subjects. (A) Speed dependence, (B) Headway dependence

4.4ブレーキ踏み込み時間 図7（A）には，ブ レ一キ踏み込み時間の同一車間距離における車速依 存性を示した. グラフは, 3 人の被験者の平均値で ある. 誤差バーは, 全データの標準誤差である. 分 散分析の結果, 車速と運転状態の交互作用のみが有
意であった（車速 $\times$ 運転状態：F(2, 82)=3.91， $\mathrm{P}<0.05 ）$ ．下位検定の結果，能動状態では，車速依 存性が見られず，受動状態では $10 \mathrm{~km} / \mathrm{h}$ と $30 \mathrm{~km} / \mathrm{h}$ 条 件との間に有意な差が見られ，速度が高いほど短時 間で最大值に達していた. 速度 $30 \mathrm{~km} / \mathrm{h}$ 条件におい て能動・受動運転間でブレーキ踏み込み時間の差が 見られたが，全速度条件を通しては，能動・受動運 転間の車速依存性の有意差を見出せなかった（運転 状態 : $F(2,82)=0.599, \quad P=0.441)$.

図 7（B）には,ブレーキ踏み込み時間の同一車 速における車間距離依存性を示した．分散分析の結 果，車間距離の主効果および車間距離と運転状態の 交互作用が有意であった.（車間距離 : F $(2,82)=$ 9.24, $\mathrm{P}<0.01$; 車間距離 $\times$ 運転状態 : $\mathrm{F}(2,82)=4.67$, $\mathrm{P}<0.05 ）$. 下位検定の結果, 受動運転においてのみ, 車間距離の増加とともに最大值になるまでの時間が 増加する距離依存性が見られた. また能動・受動運 転間には，車間距離 $20 \mathrm{~m}$ の条件においてのみ時間 差が存在したが, 平均的な差は有意とは言えなかっ た（運転状態 : $F(2,82)=0.284, P=0.595 ）$.
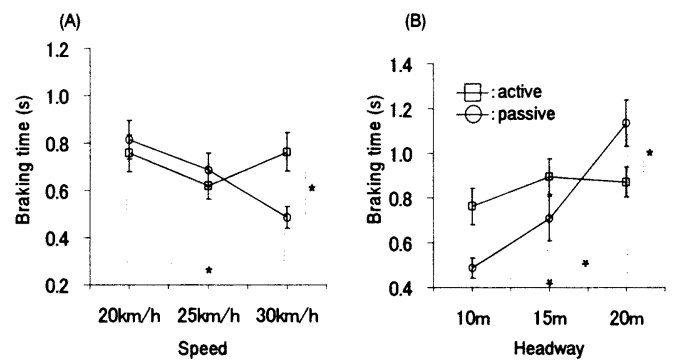

Fig. 7 Braking time averaged by three subjects. (A) Speed dependence, (B) Headway dependence

4.5 最大ブレーキ圧 図 8(A)では, 同一車間距離 において，車速がブレ一キ圧の最大值に与える影響 を検討した. 分散分析の結果，車速および運転状態 の主効果, 車速と運転状態の交互作用が有意であっ た. （車速: $F(2,82)=92.1$, 運転状態: $F(2,82)=$ 22.8, $P<0.01$; 車速 $\times$ 運転状態 : $F(2,82)=3.70$, $\mathrm{P}<0.05 ）$ ．交互作用が有意であったが，その程度は 小さく, 速度 $25 \mathrm{~km} / \mathrm{h}, 30 \mathrm{~km} / \mathrm{h}$ では, 最大ブレーキ 圧が運転状態によって異なっていた．速度の増加と ともにブレーキ圧の最大值が増加する傾向は，能 動・受動両運転で見られた。

図 8(B)では, 同一車速において, 車間距離がブ レ一キ圧の最大值に与える影響を検討した. 分散分 析の結果, 車間距離および運転状態の主効果, 車間 距離と運転状態の交互作用が有意であった。（車間 距離 : $F(2,82)=84.5, P<0.01$; 運転状態 : $F(2,82)=$ 
22.8, $\mathrm{P}<0.01$; 車間距離 $\times$ 運転状態 : $\mathrm{F}(2,82)=5.31$, $\mathrm{P}<0.05 ）$ ．交互作用が有意であったが，その程度は 小さく, 車間距離 $10 \mathrm{~m}, 20 \mathrm{~m}$ では, 最大ブレ一キ圧 が運転状態によって異なっていた. 各運転状態にお いて車間距離の増加とともにブレーキ圧の最大值が 減少する傾向は, 共通していた.
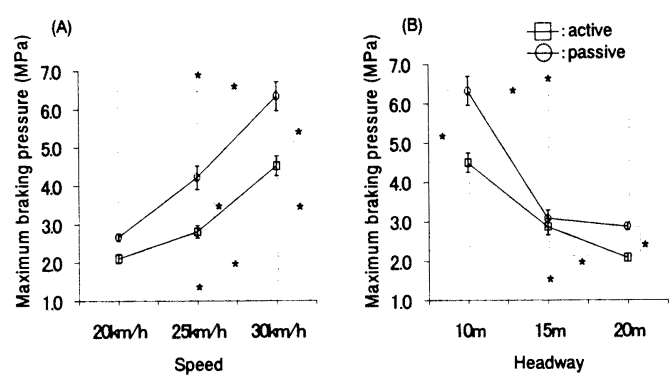

Fig. 8 Maximum braking pressure averaged by three subjects. (A) Speed dependence, (B) Headway dependence

4.6停止距䧺 図9(A)に能動運転実験, 図9(B)に 受動運転実験における, 各被験者の平均停止距離を 示した. 縦軸は停止距離を, 横軸は実験条件を示し ている. 黒色のグラフは被験者 A.M., 斜線のグラ フは被験者 S.T., そして白色のグラフは被験者 N.Y. のデータである.

受動運転実験時のグラフでは, 一定車間距離条件 下において, 車速が速くなるほど停止距離が長くな ること, また, 一定車速条件下のときには, 車間距 離が長くなるほど停止距離が長くなることがわかつ た. また能動運転実験時のグラフにおいても, 一定 車速条件下のとき車間距離が長くなるほど停止距離 が長くなり, 一定車間距離条件下のときでは, 車速 が速くなるほど停此距離が長くなることがわかった. 異なる運転条件間では, 大きな差は見られなかった.

図 10(A)では, 同一車間距離において, 車速が停 止距離に与える影響を検討した. 分散分析の結果, 車速の主効果および車速と運転状態の交互作用が有 意であった.（車速 : $F(2,82)=45.7, P<0.01$; 車速 $\times$ 運転状態： $F(2,82)=9.87, P<0.01 ）$. 交互作用が有意 であったので，下位検定を実施した．図10(A)から わかるように, 交互作用は, 速度 $30 \mathrm{~km} / \mathrm{h}$ に存在し た. 車速の増加により, 停止距離が増加するという 依存性は, 能動・受動運転条件で一致した。

図 10(B)では, 同一車速において, 車間距離が停 止距離に与える影響を検討した. 分散分析の結果, 車間距離の主効果と車間距離と運転状態の交互作用 が有意であった（車間距離 : $\mathrm{F}(2,82)=7.33, \mathrm{P}<0.01$; 車間距離 $\times$ 運転状態: $F(2,82)=3.66, P<0.05)$. 交互
作用が有意であったがその程度は弱く, 下位検定の 結果, 運転条件間で停止距離の車間距離依存傾向が 変わることは無かった. すなわち, 能動・受動両運 転条件において, 車間距離の増加とともに停止距離 が増加する距離依存性が存在した.

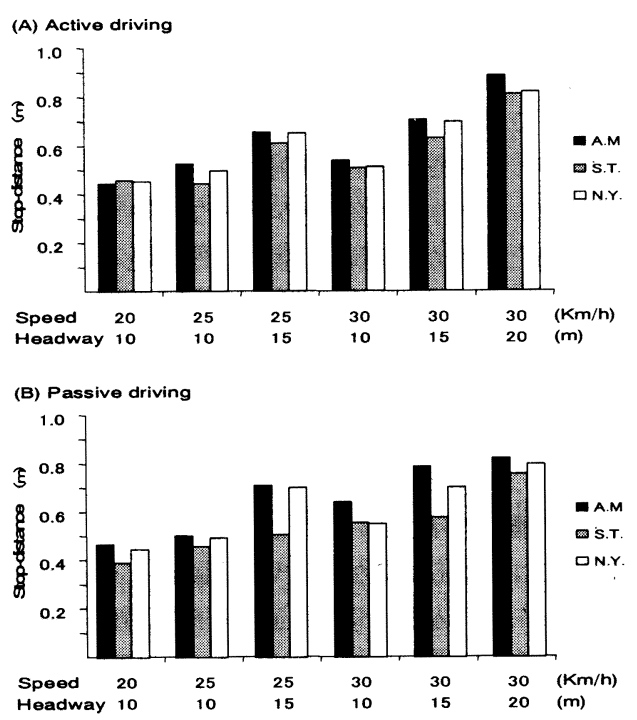

Fig. 9 Averaged stop-distance of each experimental condition in active (A) and (B) passive driving experiment
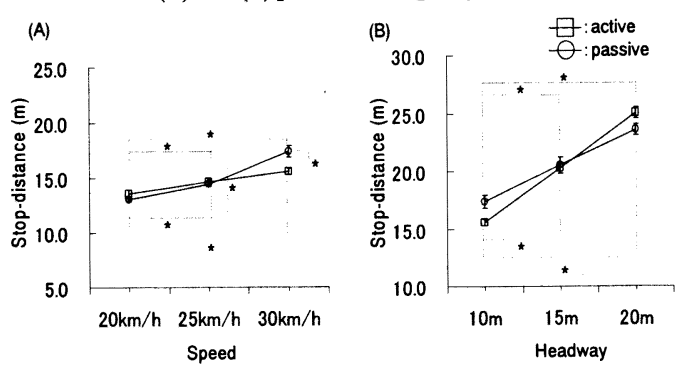

Fig. 10 Stop-distance averaged by three subjects. (A) Speed dependence, (B) Headway dependence

5. 考

本実験では, 能動運転と受動運転の 2 つ運転 状態に置かれた被験者が, 緊急停止に直面した時の 行動特性を実車実験により評価した。本研究では, 緊急時行動を複数の行動要素から成る複合的行動之 考えており，それに応じた複数の行動時間を設定し た ${ }^{(8)}$. 以下, 各行動時間について考察する.

図 6 に示したように最大ブレ一キ圧時間は, 速 度・車間距離依存性の運転状態における差はほとん どなく, いずれも車速の増加と車間距離の減少とい う, より緊急なブレーキ操作を必要とする場合に最 大ブレーキ圧時間が短くなる傾向を示した. これは, 被験者が, 運転状態にかかわらず「停止線までに停 
止せよ」という実験指示に従い, 速度に応じた緊急 行動を起こしたためだと考えられる. 事際, 図 10 で示したように, 緊急時行動の結果としての停止距 離においても能動・受動運転間で大きな差は見られ ず，被験者が，運転状態にかかわらずできるだけ早 い停車を行ったことが見受けられる.このように, 緊急時行動全体を検討した場合，あるいは，その結 果としての停止距離を検討した場合には，運転状態 に依存した差を積極的に見出すことができなかった. その一方で, 信号変化からのブレーキ圧の推移 を見ると明らかな運転状態依存性が見られる（図 3）。そこで, 最大ブレ一キ圧時間を反応時間とブ レ一キ踏み込み時間とに分けて, その運転状態依存 性を検討した結果が図 5 と図 7 である. その結果, 能動運転時には, 反応時間が車速や車間距離に依存 し, その一方で, ブレ一キ踏み込み時間は, 車速や 車間距離に依存しない傾向が見られ, 逆に, 受動運 転時には, 反応時間が車速や車間距離に依存せず, ブレーキ踏み込み時間が車速や車間距離に依存する という結果が得られた.

受動運転時に得られた反応時間の車速や車間距 離への非依存性には, 複合的な要因が考えられる. 受動運転時, 足の初期位置は常に床面でありブレ一 キへの移動時間は, 常に一定になりうる.これは, アクセル・ブレーキ操作を必要とし，したがって足 の初期位置が一定しない能動運転時とは異なってい る. しかしながら, 能動運転時における反応時間の 車速や車間距離依存性を考えると, 本結果が単純に 移動時間によるものではないことがわかる. 能動運 転時には足の初期位置が一定しないという状況にも かかわらず，車速が速く車間距離が短いというより 緊急の操作を必要とする場合には, 反応時間が短く なっている. もしも, 被験者が緊急時において, 常 に同一の行動を試みるならば, 受動運転においても 車速や車間距離への依存性が見られるはずである.

ここにおいて, 我々は, 能動・受動運転の緊急 時行動への影響を考えている. 能動運転時, ドライ バは五感を通して得られる環境情報を基に次に取る べき行動を選択している. そして，その行動の結果 が自動車を通じて環境へと作用し再びドライバに知 覚されるため, ドライバは, 行動, 自動車, 環境, 知覚からなる閉ループの中に存在していると考えら れる. 能動運転条件において, 緊急時行動は車速や 車間距離などの環境情報には依存した. 能動運転中, ドライバは, 速度や車間距離などの環境情報に応じ た行動を行っており,したがって緊急事態に直面し
たとしてもこれらの環境情報に応じた行動をとるこ とができたと考えられる. 一方, 受動運転条件では, 緊急時行動が車速や車間距離などの環境情報に依存 しなかった. 受動運転中において, これらの嘸境情 報と行動との関連性は, 能動運転に比べて低く, し たがって緊急時行動においても明確な関連性が得ら れなかったと考えられる.

本実験の反応時間は, 黄色信号に気付き足運動 を開始するまでの時間とそれに続いてブレーキペダ ル操作を開始するまでの時間の和であり, すでに複 合的な行動パラメータとなっている. 本実験では, 足の運動の計測は車内ビデオ画像のみに拠つたため 十分な計測精度を得ることができなかった. どちら の行動パラメータが運転状態に依存するのかを検討 するためには，筋電図測定などにより運動開始時間 を正確に測定する必要がある.これは, 今後の課題 である.

ブレーキ踏み込み時間に関しては, 反応時間と は逆に, 受動運転時に速度・車間距離依存性が見ら れた（図 7）。本課題では, 停止線までに止まると いう目標が存在し, 被験者は運転状態によらずこれ を実現するような緊急時行動をとっていた（図 6,

図 10）。受動運転時, 被験者は, 反応時間が車速 や車間距離に依存しないことによって生じた時間的 余裕や遅延をそれに続くブレ一キ踏み込み行動の時 間を調節することで埋め合わせる方策を採ったもの と考えられる. 特に車速が速く車間距離が短い緊急 の操作を必要とする条件 (車速 $30 \mathrm{~km} / \mathrm{h}$, 車間距離 10m）においては，その傾向が顕著であった. また, このような条件では, 最大ブレーキ圧データも受動 運転時に大きく（図 8），すなわち短時間に大きな ブレーキ力を発生させること（急ブレ一キ）により 自動車を制御したものと考えられる.

以上をまとめた概念図を図 11 に示す. 複合的行 動としての緊急時行動には, 受動・能動の運転状態 間の差を積極的に見出せなかった. 複合的行動の要 素としての信号への応答（反応時間）とブレーキ操 作（ブレ一キ踏み込み時間）へ，異なる影響をした。 能動運転は, 車速や車間距離などの環境情報に即し た反応時間とそれに続く比較的安定したブレ一キ操 作で特徴付けられた. 一方, 受動運転では, 反応時 間が車速や車間距離などの環境情報に依存しなかつ た. しかしながら，そのままでは能動運転時と同様 な停止位置を実現することができないために, 反応 時間に続くブレーキ操作を変化させることで緊急時 に対処した. 結果として, ブレーキ踏み込み時間が 
車速や車間距離に影響を受けた.このような受動運 転特性は, 車速が速い場合や車間距離が短い場合に 急ブレーキをもたらす可能性がある. ACC システ ム作動時におけるブレ一キ特性は, このような受動 運転特性に合わせて通常運転時とは変える必要があ るかもしれない.
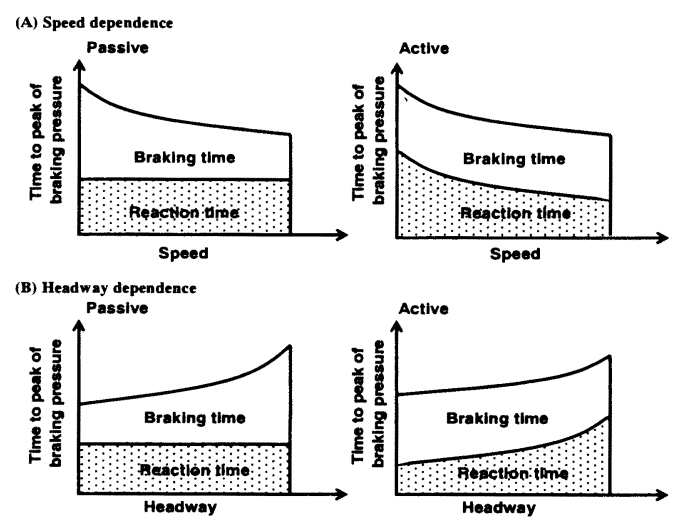

Fig. 11 Time to peak of braking pressure averaged by three subjects. (A) Speed dependence, (B) Headway dependence 本実験は, 速度 $10 \mathrm{~km} / \mathrm{h}$ から $30 \mathrm{~km} / \mathrm{h}$ の比較的低速 域における運転行動特性を評価したものである. 本 結果が, 中高速域におけるドライバの運転行動にま で一般化できるかどうかは，今後の検討を必要とす る.

\section{6. 結}

本研究では, ドライバ本人がアクセル・ブレー キペダルを操作する能動運転と, ACC システムが それらを行う受動運転の 2 つ運転状態にて先行車 両を追従しているという場面を想定した. そこで, ドライバが緊急停止の事象に直面した時のドライバ の操作・行動特性を反応時間やブレーキ圧などの指 標を基に定量的に評価した.

その結果, 運転状態の違いは, 緊急時行動全体 を特徵付ける指標である最大ブレ一キ圧時間や停止 距離に対して積極的に影響しなかったが，緊急時行 動を信号への応答（反応時間）とブレーキ操作（ブ レーキ踏み込み時間) の要素からなる複合的行動と 捉えると, 各要素に異なる影響を及ぼすことが分か った. 能動運転は，車速や車間距離などの環境情報 に応じた反応時間とそれに続く比較的安定したブレ 一キ操作で特徵付けられた. 一方, 受動運転では, 反応時間が車速や車間距離などの環境情報に依存し
なかったが，ドライバはそれに続くブレーキ操作を 環境情報に応じて変化させることで緊急時に対処し た.

本実験の結果は, ACC システムにおける先行車 追従機能が，ドライバの運転行動に影響を及ぼすこ と, 加えて, このようなシステムの評価を行う際に ドライバの運転行動を複合的行動として捉える重要 性を示している.

謝 辞 本研究の被験者と協力者としてご協力 を頂いた香川大学工学部吳研究室の各位に感謝いた します. なお, 本研究の一部分は文部科学省科学研 究費補助金（基盤研究(B):17360117）の支援を受け ました.ここに記して謝意を表します.

\section{文献}

(1) Yamamoto, Y. et al., Development of Mazda ASV-2, MAZDA TECHNICAL REVIEW, Vol. 19, (2001), pp. 64- 72.

(2) Ninomiya, Y., Driving Environment Recognition in ITS, Proceedings of 12th Communication Systems Workshop on Information, Communication and Signal Processing, (1999), pp. 7-11.

(3) Uno, H. et al., Effect of Driving Support Function on Driver Arousal Level During Driving, JARI Research Journal, Vol. 24, No. 9 (2002), pp. 25-28.

(4) Takahashi, H. and Sato, H., A Study on Relationship Between Driver and Vehicle in Automatic Controlled System Environments. The Case of Adaptive Cruise Control System from a Cognitive Science Point of View, Journal of the Society of Automotive Engineers of Japan, Vol. 52, No.10 (1998), pp. 74- 79.

(5) Kojima, S. et al., Comparison between the Active Speed Reduction Timing and the Passive one to the Slowdown of the Preceding Car, Proceedings (2002 JSAE Spring Convention), No. 97-02 (2002), pp. 5- 8.

(6) Hirose, T. et al., Research on the Difference in Sensitivity between the Activity and the Passivity in Advanced Vehicle Control and Safety System, Proceedings of Japan Ergonomics Society Kanto Branch, (2003), pp. 85- 86.

(7) Marumo, Y. et al., Effects of Low-Speed ACC Function on Driver Behavior, JARI Research Journal, Vol. 25, No.7 (2003), pp. 279- 282.

(8) Yang, Z. et al., Research on Detection of Precede Braking Reaction, Transactions of Society of Automotive Engineers of Japan, Vol. 35, No.4 (2004), pp. 185- 190. 